Available online on 15.03.2020 at http://jddtonline.info
Open Access to Pharmaceutical and Medical Research
(c) 2011-18, publisher and licensee JDDT, This is an Open Access article which permits
unrestricted non-commercial use, provided the original work is properly cited

Open Access

Research Article

\title{
Antioxidant Activity of Centaurium erythraea Extracts
}

\author{
Mounira Merghem* and Saliha Dahamna
}

Laboratory of Phytotherapy Applied to Chronic Diseases, Department of biology and animal physiology, Faculty of Natural and Life Sciences, Ferhat Abbas University, Sétif 19000, Algeria

\begin{abstract}
Phototherapy has known a great evolution all the world and some medicinal plants are importance remedies of some diseases. Centaurium erythraea is one of the medicinal plants widely used in this field. In this study, we have evaluated the total polyphenolic and the flavonoid contents of the methanolic (ME) and aqueous (AqE) extracts of the plant Centaurium erythraea as well as its antioxidant activity using the DPPH (2'2-diphenylpicrylhydrazyl), $\beta$-carotene /linoleic acid bleaching and reducing power assays. The total polyphenolic content of the methanolic

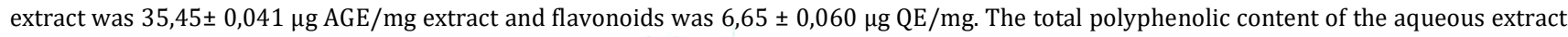
was $54,27 \pm 0,023 \mu \mathrm{g} \mathrm{AGE} / \mathrm{mg}$ extract and flavonoids was $3,275 \pm 0,003 \mu \mathrm{g} \mathrm{QE} / \mathrm{mg}$. The results of the DPPH test showed a powerful antioxidant activity with a very similar $\mathrm{IC}_{50}$ for the methanolic ( $\mathrm{IC}_{50}=0.232 \pm 0.002 \mathrm{mg} / \mathrm{ml}$ ) and aqueous $(0.208 \pm 0.002 \mathrm{mg} / \mathrm{ml})$ extracts. The inhibitory activity of the tow extracts in the $\beta$-carotene/linoleic acid assay was $(86.781 \pm 0.17 \%)$ for the methanolic extract and $(77.816 \pm 0.69 \%)$ for the aqueous extract. ME has the higher reducing power $\left(\mathrm{IC}_{50}=0.35 \pm 0.066 \mathrm{mg} / \mathrm{ml}\right.$ ) compared to the $\mathrm{AqE}\left(\mathrm{IC}_{50}=1.31 \pm 0.047 \mathrm{mg} / \mathrm{ml}\right)$.
\end{abstract}

Keywords: Centaurium erythraea, antioxidant activity, polyphenols, DPPH scavenging, $\beta$-carotene, reducing power.

Article Info: Received 11 Jan 2020; Review Completed 23 Feb 2020; Accepted March 02 2020; Available online 15 March 2020

Cite this article as:

Merghem M, Dahamna S, Antioxidant Activity of Centaurium erythraea Extracts, Journal of Drug Delivery and Therapeutics. 2020; 10(2):171-174 http://dx.doi.org/10.22270/jddt.v10i2.3935

*Address for Correspondence:

Mounira Merghem, Laboratory of Phytotherapy Applied to Chronic Diseases, Department of biology and animal Mounira Merghem, Laboratory of Phytotherapy Applied to Chronic Disease
physiology, Faculty of Natural and Life Sciences, Ferhat Abbas University, Sétif 19000, Algeria

\section{INTRODUCTION}

Free radicals are chemical species which contains one or more unpaired electrons due to which they are highly unstable and cause damage to other molecules by extracting electrons from them in order to attain stability. Living cells generate free radicals and other reactive oxygen species (ROS) by-products as a result of physiological and biochemical processes. ${ }^{1}$ ROS are various forms of activated oxygen, which include free radicals such as superoxide anion radicals $\left(\mathrm{O}^{2-}\right.$ ) and hydroxyl radicals $(\mathrm{OH} \cdot)$, as well as nonfree radical species $\left(\mathrm{H}_{2} \mathrm{O}_{2}\right)$ and the singled oxygen $\left(10^{2}\right)$. ${ }^{2,3}$ Also, excessive generation of ROS, induced by various stimuli and which exceed the antioxidant capacity of the organism, leads to a variety of pathophysiological processes such as inflammation, diabetes, genotoxicity, and cancer. ${ }^{4}$

Antioxidant is any substance, which when present even at low concentrations, compared with those of an oxidizable substrate, significantly delays or prevents oxidation of substrate. The term 'oxidizable substrate' includes almost everything found in the living cells including proteins, lipids, DNA and carbohydrates. ${ }^{5}$
Research has shown that several medicinal plants possess chemical substances that display antioxidant potentials. Natural antioxidants from the intake of plant parts have been reported to reduce the adverse effect of free radicals that normally occur during cell metabolism. Plant phenolics are principally the source of natural antioxidants and are originally derived from plant parts including seeds, nuts, roots, barks, and leaves. 6

Centaurium erythraea, of the Gentianaceae family, has been used in traditional medicine. It was reported that the decoction of the whole plant has been used to treat urine retention, colic and diabetes mellitus (centuruim erethraea) Extracts of its aerial parts, in the form of tinctures, tonics, lotions or tea, have been traditionally used to treat gastrointestinal disorders, dyspepsia, constipation, fever, anemia, anorexia, hepatitis, jaundice, rheumatism, wounds and sores, to stimulate appetite, and to cleanse blood and kidneys.7,8 Centaurium erythraea extracts also possess antimutagenic, ${ }^{9}$ hepatoprotective, diuretic, antitumorigenic, analgesic, antipyretic, anti-inflammatory, ${ }^{10}$ gastroprotective, antiulcer, ${ }^{11}$ antioxidative, antibacterial and antifungal properties. ${ }^{12}$ 


\section{MATERIALS AND METHODS}

\section{Chemicals}

Folin-Ciocalteu, aluminum chloride $\left(\mathrm{AlCl}_{3}\right)$, gallic acid, quercetin, rutin, 2,2-diphenyl-1-picrylhydrazyl hydrate (DPPH), ethylenediaminetetraacetic acid (EDTA), gallic acid and tween 40 were purchased from Sigma Chemical Co. (St. Louis, MO). Linoleic acid, $\beta$-carotene and butylated hydroxytoluene (BHT) were obtained from Fluka Chemical Co. (Buchs, Switzerland). Ferrous and ferric chloride were obtained from Merck. All other reagents were of analytical grade.

\section{Plant material}

Centaurium erythraea was collected in December, Wilaya of Sétif in Northeast of Algeria, plant material were cleaned with tap water, dried in the shade at room temperature for 2 weeks and ground into powder using an electric grinder.

\section{Preparation of plant extract}

\section{Aqueous extract}

$100 \mathrm{~g}$ of Centaurium erythraea powder was mixed with $1 \mathrm{~L}$ of boiling distilled water $\left(100{ }^{\circ} \mathrm{C}\right)$ and after 20 minutes it was removed from the heat. The mixture was filtered using Wattman filter paper $n^{\circ} 3$ and then evaporated in rotary vacuum evaporator at $45^{\circ} \mathrm{C}$.

\section{Methanolic extract}

The methanolic extract was obtained by maceration in water/methanol mixture $115: 85)$ for $24 \mathrm{~h}$. The resultant extract was filtered through Wattman paper $n^{\circ} 3$ and the solvent was removed by rotary evaporator under reduced pressure at $45^{\circ} \mathrm{C}$. The resulting extract was then stored at $20^{\circ} \mathrm{C}$ until further analysis.

\section{Determination of total polyphenol content}

Total phenolic content was determined using Folin-Ciocalteu method, according to ${ }^{13}$ with slight modifications. A volume of $100 \mu \mathrm{l}$ of the extract was mixed with $500 \mu \mathrm{l}$ of FolinCiocalteau (diluted $10 \%$ in distilled water). After $4 \mathrm{~min}, 400$ $\mu \mathrm{l}$ of sodium carbonate solution $\mathrm{Na}_{2} \mathrm{CO}_{3}(75 \mathrm{~g} / \mathrm{l})$ was added to the mixture, the reaction mixture was incubated at room temperature for $1 \mathrm{~h} 30 \mathrm{~min}$ and the absorbance of the mixture was measured at $760 \mathrm{~nm}$, Gallic acid (20-140 mg/l) was used as standard for the calibration curve. The total polyphenols content was expressed as micrograms of gallic acid equivalents (GAE) per milligram of extract. All samples were analyzed in three replications.

\section{Determination of total flavonoids contents}

The total flavonoids in plant extracts were determined using the aluminum trichloride $\left(\mathrm{AlCl}_{3}\right)$ method. ${ }^{16}$ Briefly, $1 \mathrm{ml}$ of $2 \% \mathrm{AlCl}_{3}$ in methanol was mixed with $1 \mathrm{ml}$ of the extract. After incubation in dark at room temperature for $10 \mathrm{~min}$, the absorbance of the reaction mixture was measured at $430 \mathrm{~nm}$. Quercetin (1-40 mg/l) was used as standard for calibration curve and the total Flavonoids content was expressed as micrograms quercetin equivalent (QE) per milligram of extract.

\section{Evaluation of antioxidant activity}

\section{DPPH free radical-scavenging assay}

The free radical scavenging activity of the extracts was measured by 2,2- diphenyl-1-picrylhydrazyl(DPPH) assay. 15 After dissolving the aqueous extract in distilled water, the methanol extract in methanol, the solution of DPPH in methanol $(0.04 \mathrm{mg} / \mathrm{mL})$ was prepared and $1250 \mu \mathrm{L}$ of this solution was added to $50 \mu \mathrm{L}$ of extracts solution at different concentration. The mixture was shaken vigorously and then kept in the dark for 30 minutes at room temperature. Then, the absorbance was measured at $517 \mathrm{~nm}$. BHT, rutin, quercetin and gallic acid were used as standards. All tests were performed in triplicate. Radical-scavenging activity was calculated using the following equation:

$$
\text { radical scavenging activity }(\%)=\left(\mathrm{A}_{\text {blank }}-\mathrm{A}_{\text {sample }} / \mathrm{A}_{\text {blank }}\right) \times 100
$$

A blank: Absorbance of the control.

A sample: Absorbance of the reagent with extract.

\section{$\boldsymbol{\beta}$-carotene/linoleic acid assay}

In this test, the antioxidant capacity of the extracts was determined by measuring the inhibition of the oxidative degradation of $\beta$-carotene (discoloration or bleaching) by the oxidation products of the acid linoleic. ${ }^{16}$ The $\beta$-carotene solution was prepared by dissolving $0.5 \mathrm{mg} \beta$-carotene in 1 $\mathrm{mL}$ of chloroform. One milliliter of this solution was pipetted to a flask covered with aluminum foil. Then $25 \mu \mathrm{L}$ of linoleic acid and $200 \mathrm{mg}$ of tween 40 were added. The chloroform was evaporated using evaporator at $45^{\circ} \mathrm{C}$. Then $100 \mathrm{~mL}$ of distilled water saturated with oxygen was added. $2.5 \mathrm{~mL}$ of this prepared $\beta$-carotene solution were transferred to test tubes, and $350 \mu \mathrm{L}$ of the extracts $(2 \mathrm{mg} / \mathrm{mL}$ methanol) were added before incubation for $48 \mathrm{~h}$ at room temperature. The same procedure was repeated with butylated hydroxyl toluene (BHT) as a positive control and with distilled water as a negative control. The absorbance was reading at $490 \mathrm{~nm}$ after $1 \mathrm{~h}, 2 \mathrm{~h}, 6 \mathrm{~h}, 24 \mathrm{~h}$ and $48 \mathrm{~h}$. The antioxidant activity of extracts was calculated using the following equation:

$$
\mathrm{AA} \%=\mathrm{A}_{\text {sample }} / \mathrm{A}_{\mathrm{BHT}} \times 100 .
$$

A sample: Absorbance in the presence of the Extract; $\mathrm{A} \mathrm{внт:}$ Absorbance in the presence of positive control BHT.

\section{Reducing power}

Reducing power was determined on the basis of the ability of antioxidant principles to form colored complex with potassium ferricyanide, TCA and $\mathrm{FeCl}_{3}$ and it was measured by the method reported by. ${ }^{17} 1 \mathrm{~mL}$ of extract was mixed with $0.5 \mathrm{~mL}$ phosphate buffer $(0.2 \mathrm{M}, \mathrm{pH} 6.6)$ and $0.5 \mathrm{~mL}$ potassium ferricyanide $(1 \% \mathrm{w} / \mathrm{v})$. The mixture was incubated at $50^{\circ} \mathrm{C}$ for $20 \mathrm{~min}$. After terminating the reaction by adding trichloroacetic acid $(10 \% \mathrm{w} / \mathrm{v})$, the mixture was centrifuged at $3000 \mathrm{rpm}$ for $10 \mathrm{~min}$. The supernatant of solution $0.5 \mathrm{~mL}$ was mixed with $0.5 \mathrm{~mL}$ distilled water and $0.1 \mathrm{~mL} \mathrm{FeCl} 3(0.1 \% \mathrm{w} / \mathrm{v})$. After $5 \mathrm{~min}$ later, the absorbance was measured at $700 \mathrm{~nm}$. Higher absorbance of the reaction mixture indicated higher reducing power.

\section{Statistical Analyses}

The results are expressed as the mean \pm standard deviation. One-way analysis of variance (ANOVA) followed by the Tukey test was performed to assess differences between groups. Differences were considered significant at $\mathrm{p}<0.05$.

\section{RESULTS AND DISCUSSION}

\section{Total phenolic and flavonoid content}

Polyphenols of plant kingdom are one of the most effective antioxidative constituents. It is important to estimate phenolic contents of plant extracts so as to justify their contribution to antioxidant activity. ${ }^{18}$ The content of phenolic compounds in extracts was determined from regression equation of calibration curve of Gallic acid and expressed as micrograms equivalent of Gallic acid per 
milligrams of dry extract ( $\mu$ g GAE/mg extract). Flavonoids content was expressed as micrograms equivalent of Quercetin per milligrams of dry extract ( $\mu \mathrm{g} \quad \mathrm{QE} / \mathrm{mg}$ extract).Table 1 showed the total content of phenolics and flavonoids in extracts. AqE extract had a total phenolic content of $(54,27 \pm 0,023 \mu \mathrm{g} \mathrm{GAE} / \mathrm{mg}$ extract $)$ and flavonoids $\quad(3,275 \pm 0,003 \mu \mathrm{g} \mathrm{QE} / \mathrm{mg}$ extract $)$. while, Methanolic extract had a total phenolic content of $(35,45 \pm$ $0,041 \mu \mathrm{g} \mathrm{GAE} / \mathrm{mg}$ extract) and flavonoids $(6,65 \pm 0,06 \mu \mathrm{g}$ $\mathrm{QE} / \mathrm{mg}$ extract).

Table 1. Total polyphenols and flavonoids content of Centaurium erythraea extracts.

\begin{tabular}{ccc}
\hline Extract & $\begin{array}{c}\text { Polyphenols } \\
\mu \mathrm{GAE} / \mathrm{mg} \text { extract }\end{array}$ & $\begin{array}{c}\text { Flavonoids } \\
\mu \mathrm{g} \text { QE/mg extract }\end{array}$ \\
\hline $\mathrm{AqE}$ & $54,27 \pm 0,023$ & $3,275 \pm 0,003$ \\
\hline $\mathrm{ME}$ & $35,45 \pm 0,041$ & $6,65 \pm 0,060$
\end{tabular}

$\mathrm{ME}$ : methanolic extract, AqE : aqueous extract, GAE: gallic acid equivalent, QE: quercetin equivalent. Each value represents the mean \pm SD $(n=3)$

Extraction of phenolic compounds is strongly affected by their chemical nature, the sample particles size, the extraction method employed, and the presence of interfering substances. Moreover, the solubility of phenolic substances is strictly dependent by the polarity of the solvent used, as well as their degree of polymerisation. ${ }^{19}$

\section{DPPH radical scavenging activity}

DPPH is a stable radical showing a maximum absorbance at $517 \mathrm{~nm}$. It can readily undergo reduction by an antioxidant $(\mathrm{AH})$ which can be demonstrated by the following reaction. ${ }^{20}$

$$
\mathrm{DPPH}+\mathrm{AH} \longrightarrow \mathrm{DPPH}-\mathrm{H}+\mathrm{A}
$$

In the present study, the ability of extract to scavenge DPPH was assessed on the bases of their IC 50 values, defined above as the concentration of extract to decrease the absorbance at $517 \mathrm{~nm}$ (or concentration) of DPPH solution to half of its initial value. The DPPH free radical-scavenging activities of Centaurium erythraea extracts are presented in table 2.

The results of the DPPH test showed a powerful antioxidant activity with a very similar $\mathrm{IC}_{50}$ for the methanolic $\left(\mathrm{IC}_{50}=0.232 \pm 0.002 \mathrm{mg} / \mathrm{ml}\right)$ and aqueous $(0.208 \pm$ $0.002 \mathrm{mg} / \mathrm{ml}$ ) extracts.

Table 2: DPPH scavenging activity of Centaurium erythraea extracts and standards.

\begin{tabular}{cc}
\hline Extracts & $\mathrm{IC}_{50}(\mathrm{mg} / \mathrm{mL})$ \\
\hline ME & $0.232 \pm 0.002$ \\
AqE & $0.208 \pm 0.002$ \\
Gallic acid & $0.056 \pm 0.001^{\#}$ \\
Quercetin & $3.491 \pm 0.001^{\#}$ \\
\hline
\end{tabular}

\#: $\mu \mathrm{g} / \mathrm{ml}$. Each value represents the mean \pm SD $(\mathrm{n}=3)$.

$\beta$-carotene/linoleic acid bleaching assay

Generally in the $\beta$-carotene bleaching assay, linoleic acid produces hydroperoxides as free radicals during incubation and with presence of antioxidants in the extract, it will minimize the oxidation of $\beta$-carotene by hydroperoxides. Hydroperoxides formed in this system will be neutralized by the antioxidants from the extracts. ${ }^{21}$ Thus, the degradation rate of $\beta$-carotene depends on the antioxidant activity of the extracts. There was a correlation between degradation rate and the bleaching of $\beta$-carotene; where the extract with the lowest $\mathrm{b}$-carotene degradation rate exhibited the highest antioxidant activity. ${ }^{22}$

The results of the inhibition of $\beta$-carotene oxidation in the presence of extracts after 24 hours of incubation was presented in table 3 . The antioxidant activity of the tow extracts in the $\beta$-carotene/linoleic acid assay was (86.781 \pm $0.17 \%)$ for the methanolic extract and $(77.816 \pm 0.69 \%)$ for the aqueous extract.

Table 3. Antioxidant activities of Centaurium erythraea extracts at 24 hours of incubation measured by $\beta$-carotene bleaching method.

\begin{tabular}{cc}
\hline Extracts & Inhibition \% \\
\hline ME & $86.781 \pm 0.17$ \\
AqE & $77.816 \pm 0.69$ \\
BHT & $100 \pm 0.23$ \\
H2O & $14.827 \pm 0.48$ \\
\hline
\end{tabular}

Each value represents the mean $\pm \operatorname{SD}(n=3)$.

\section{Reducing power}

The antioxidant compounds are responsible for the reduction of ferric $\left(\mathrm{Fe}^{3+}\right)$ form to ferrous $\left(\mathrm{Fe}^{2+}\right)$ form. The addition of $\mathrm{FeCl}_{3}$ to the ferrous form led to the formation of blue colored complex. So the reduction ability can be determined by measuring the colored complex at $700 \mathrm{~nm}$. The reducing properties associated with the presence of compounds exert their action by breaking the free radical chain through donating a hydrogen atom. ${ }^{23}$

The reducing power of the extract was presented in Table 4. $\mathrm{ME}$ has the higher reducing power $\left(\mathrm{IC}_{50}=0.35 \pm 0.066 \mathrm{mg} /\right.$ $\mathrm{ml}$ ) compared to the AqE (IC $50=1.31 \pm 0.047 \mathrm{mg} / \mathrm{ml})$.

Table 4. $\mathrm{IC}_{50}$ values of Centaurium eryteria extracts for reducing power test

\begin{tabular}{lc}
\hline Extracts & $\mathrm{IC}_{50}(\mathrm{mg} / \mathrm{ml})$ \\
\hline $\mathrm{AqE}$ & $1,31 \pm 0,047$ \\
$\mathrm{ME}$ & $0,35 \pm 0,066$ \\
\hline \multicolumn{2}{c}{ Each value represents the mean $\pm \mathrm{SD}(\mathrm{n}=3)}$.
\end{tabular}

It is reported that the lyophilized infusion of Centaurium erythraea possessed a potent scavenging activity for hydroxyl radical in a concentration-dependent manner and was able to chelate iron ions. ${ }^{24}$ An effective antioxidant activity was also found in Centaurium erythraea flowering tops lyophilized infusion exhibiting $\mathrm{O}_{2}{ }^{\bullet-}$ scavenging activity, which is reflected in xanthine oxidase inhibition. ${ }^{25}$ The authors conclude that the ascertained antioxidant activity may be due to the presence of several phenolic compounds in this extract, namely esters of $p$-coumaric acid, ferulic acid, sinapic acid and kaempferol. Among numerous plant-derived molecules, flavonoids and phenolic acids have been intensively studied for their free radical scavenging and antioxidant properties. ${ }^{12}$ This activity is believed to be mainly due to their redox properties, which play an important role in adsorbing and neutralizing free radicals, quenching singlet and triplet oxygen, or decomposing peroxides. 4 


\section{CONCLUSION}

The extracts of Centaurium erythraea exhibited antiradical activities toward 2,2'- diphenyl-1-picrylhydrazyl (DPPH) and acting as reducing agents and inhibiting lipid peroxidation.

\section{ACKNOWLEDGEMENT}

This work was supported by the Algerian Ministry of Higher Education and Scientific Research (MERS) and by the Algerian Agency for the Development of Research in Health (ANDRS). We express our gratitude to these organizations.

\section{REFERENCES}

1.Deepa G., Ayesha S., Aditya M. and Thankamani M. In-vitro antioxidant activity and phytochemical analysis in extracts of Hibiscus rosa-sinensis stem and leaves. Free Radicals and Antioxidants . 2012; 2:41-46.

2. Yildrim A., Oktay M. and Bilaloglu V. The antioxidant activity of the leaves of Cydonia vulgaris. Turkish J. Med. Sc. 2001; 31:23-27.

3. Gulcin, I., Oktay, M., Kufrevioglu, I. O. and Aslan, A. Determination of antioxidant activity of Lichen Cetraria islandica (L) Ach. J. Ethnopharmacol. 2002; 79:325-329.

4. Adeolu A. A., Florence O. J., Anthony J. A. and Patrick J. M. Antioxidant Properties of the Methanol Extracts of the Leaves and Stems of Celtis africana. Rec. Nat. Prod. 2009; 3:23-31.

5. Ansari A. Q., Syed Abrar A., Waheed, M. A. and Sayyed, J. A. Extraction and determination of antioxidant activity of Withania somnifera Dunal. Euro. J. Exp. Bio. 2013; 3(5):502-507.

6. Emrobowansan M. I., Patrick J. M. and Voster M. A Report on the In Vitro Antioxidant Properties of Vachellia karroo Leaf Extract: A Plant Widely Grazed by Goats in the Central Eastern Cape of South Africa. Sustainability. 2017; 164 :1-9.

7. Kumarasamy Y., Nahar L., Cox, P.J., Jaspars M., Sarker S.D. Bioactivity of secoiridoid glycosides from Centaurium erythraea. Phytomedicine. 2003; 10:344-347.

8. Subotic' A., Jankovic T., Jevremovic S. and Grubisic D. Plant tissue culture and secondary metabolites productions of Centaurium erythraea Rafn., a medical plant. In: Teixeira da Silva JA (ed) Floriculture ornamental and plant biotechnology: advances and topical issues. 1st edn. Global Science Books, London, 2006; 564-570.

9. Schimmer O. and Mauthner H. Polymethoxylated xanthones from the herb of Centaurium erythraea with strong antimutagenic properties in Salmonella typhimurium. Planta Med. 1996; 62:561-564.

10. Mroueh M., Saab Y. and Rizkallah R. 2004. Hepatoprotective activity of Centaurium erythraea on acetaminophen-induced hepatotoxicity in rats. Phytother Res. 18, 431-433.

11. Tuluce Y., Ozkol H., Koyuncu I. and Ine H. Gastroprotective effect of small centaury (Centaurium erythraea L.) on aspirin-induced gastric damage in rats. Toxicol Ind Health. 2011; 27:760-768.
12. Siler B., Zivkovic S., Banjanac T., Cvetkovic J., Nestorovic Z ivkovic J., Ciric A., Sokovic M. and Misic D. Centauries as underestimated food additives: antioxidant and antimicrobial potential. Food Chem. 2014; 147:367-376.

13. Li H.B., Cheng K.W., Wong C.C., Fan K.W., Chen F. and Jiang Y. Evaluation of antioxidant capacity and total phenolic content of different fractions of selected microalgae. Food Chemistry. 2007; 102:771-776.

14. Bahorun T., Gressier B., Trotin F., Brunete C., Dine T., Vasseur J., Gazin J.C., Pinkas M., Luycky M. and Gazin M. Oxygen species scavenging activity of phenolic extract from Hawthorn fresh plant organs and pharmaceutical preparation. Drug Research. 1996; 16.

15. Burits M. and Bucar F. Antioxidant activity of Nigella sativa essential oil. Phytotherapy Research. 2000; 14:323-328.

16. Kartal N., Sokmen M., Tepe B., Daferera D., Polissiou M. and Sokmen A. Investigation of the antioxidant properties of Ferula orientalis L. using a suitable extraction procedure. Food chemistry. 2007; 100:584-589.

17. Jayaprakash G.K., Singh R.P. and Sakariah K.K. Antioxidant activity of grape seed extracts on peroxidation models in-vitro, J.Agric Food Chem. 2001; 55:1018-1022.

18. Choi Y., Jeong H. and Lee J. Antioxidant activity of methanolic extracts from some grains consumed in Korea. Food Chemistry. 2007; 103:130-138.

19. Naczk M. and Shahidi F. Extraction and analysis of phenolics in food. Journal of Chromatography A, 2004; 1054:95-111.

20. Abdeldaiem M. H., Mohamed H. G. and Abdel-Khalek H. H. Antimicrobial and Antioxidant Activities of Rosemary Essential Oil Treated By Gamma Irradiation. J. Rad. Res. Appl. Sci. 2009; 2:819-837.

21. Othman A., Ismail A., Abdul Ghani N. and Adenan I. Antioxidant capacity and phenolic content of cocoa beans. Food Chemistry. 2007; 100:1523-1530.

22. Kulistic T., Radonic A., Katalinic V. and Milos M. Use of different methods for testing antioxidative activity of oregano essential oil. Food Chemistry. 2004; 85:633-640.

23. Labiad M.H., Harhar H., Ghanimi A. and Tabyaoui, M. Phytochemical Screening and Antioxidant Activity of Moroccan Thymus satureiö̈des Extracts. JMES. 2017; 8:2132-2139.

24. Valentão P., Fernandes E., Carvalho F., Andrade P. B., Seabra R. M. and Bastos M. L. Hydroxyl radical and hypochlorous acid scavenging activity of small Centaury (Centaurium erythraea) infusion: a comparative study with green tea (Camellia sinensis). Phytomedicine, 2003; 10:517-522.

25. Valentao P., Femandes E., Carvalho F., Andrade P. B., Seabra R. M., and Bastos M. L. Antioxidant activity of Centaurium erythraea infusion evidenced by its Superoxide radical scavenging and xanthine oxidase inhibitory activity.J. Agric. Food Chem., 2001; 49:3476-3479. 